\title{
Lectotypification of Schoenodum tenax (Restionaceae) and a note on the type of Lyginia imberbis (Anarthriaceae)
}

\author{
Barbara G. Briggs \\ National Herbarium of New South Wales, Mrs Macquaries Road, Sydney, NSW 2000, Australia; \\ email: barbara.briggs@rbgsyd.nsw.gov.au
}

\begin{abstract}
Robert Brown in 1810 made clear that the original description of Schoenodum tenax Labill. was based on collections of more than one taxon. The male material is the species currently known as Lyginia imberbis $\mathrm{R}$. Br. but the female specimens include both the species currently known as Leptocarpus tenax (Labill.) R. Br. (basionym S. tenax) and Apodasmia brownii (Hook. f.) B.G. Briggs \& L.A.S. Johnson (basionym Leptocarpus brownii). A female specimen in the Willdenow Herbarium in Berlin (B), of the species currently known as Leptocarpus tenax, is designated as lectotype of $S$. tenax; this matches the illustration and text of the protologue and preserves current usage. The type specimen of Lyginia imberbis $\mathrm{R}$. Br. is a lectotype rather than a holotype.
\end{abstract}

\section{Introduction}

In a recent publication, Briggs and Johnson (1998) divided the then recognised species of Leptocarpus among four existing and three new genera. In that work we maintained the name L. tenax for the commonest, most widespread species and the one that epitomises Leptocarpus for most Australian biologists. There we pointed out that this use could only be maintained if the type of the conserved name Leptocarpus R. Br. were changed. Later I made a formal proposal (Briggs 2001) to change the conserved type of Leptocarpus from L. aristatus R. Br. to L. tenax (Labill.) R. Br. Since that proposal was made, it has become clear that there are additional issues concerning the typification of Leptocarpus tenax and Lyginia imberbis.

\section{Lectotypification of Schoenodum tenax}

Labillardière (1806) based his description of Schoenodum and S. tenax on material of both male and female plants, and both sexes are illustrated in his Tab. 228. I have now examined the relevant Labillardière specimens in Florence (FI) and Paris $(\mathrm{P})$ and a microfiche of sheet 18267 in the Willdenow herbarium in Berlin (B). The male material in FI belongs to the taxon currently known as Lyginia imberbis $\mathrm{R}$. Br. Labillardière's female specimen in FI (sheet 188031 of the Webb Herbarium) is referable to the taxon currently known as Apodasmia brownii (Hook. f.) B.G. Briggs \& 
L.A.S. Johnson (=Leptocarpus brownii Hook. f.). However, the female material in $\mathrm{P}$ and $\mathrm{B}$ is referable to the species to which the name Leptocarpus tenax $\mathrm{R}$. Br. is presently applied. These specimens are thus considered to represent three taxa, so that only lectotypification can fix the application of the names Schoenodum and S. tenax.

Labillardière's statement in the protologue of the source of the collections is 'Habitat in capite Van-Diemen', a designation given to collections from several locations in Tasmania. This appears to be intended to apply to both the male and female specimens, but only the females could have been collected there. Nelson (1974) has drawn attention to a number of specimens of Western Australian endemics cited by Labillardière that are labelled 'capite van-Dieman'. Using the names currently in use, Lyginia imberbis is a Western Australian endemic that is common on the southern coast which was visited on the voyage of d'Entrecasteaux, when Labillardière's collections were made; Apodasmia brownii occurs in Tasmania and Victoria; while Leptocarpus tenax is found in Tasmania, the south of Western Australia and widely distributed in eastern Australia.

In determining whether previous authors have lectotypified S. tenax, the following four publications are relevant.

(1) Brown (1810) was the first to recognize that Labillardière's material of Schoenodum tenax included more than one taxon. In the Prodromus, Brown adopted the name L. tenax for the seventh species of his genus Leptocarpus and cited 'Schoenodum tenax femina. Labill. nov. holl. 2. t. 229' under his entry for that species. In the protologue of Lyginia imberbis he cited 'Schoenodum tenax mas. Labill. nov. holl. 2. t. 229'. Brown also referred to his own material, using his customary style: '(M.) v.v.' and '(M. J. D.) v.v.' respectively. Since he had not examined Labillardière's specimens (D. Mabberley pers. comm.), Brown's citation of Labillardière would refer to the excellent illustrations, rather than directly to Labillardière's specimens. Also, Brown did not use the word 'type', or equivalent.

(2) In his Enumeratio Plantarum, Kunth (1841) widened the circumscription of Schoenodum, equating it with 'Leptocarpi species Brown' and excluded Labillardière's male plant. Although he referred specifically to Labillardière's collection in the Willdenow herbarium he did not formally refer to it as lectotype.

(3) Rickett \& Stafleu (1959), in their review of Appendix III of the International Code of Botanical Nomenclature (Paris 1956), state about Lyginia, 'Conservation superfluous: Schoenodum Labillardière ... need not be rejected because its type S. tenax is typified by the female plant of Labillardière, which is Leptocarpus R. Brown ... and not Lyginia.' [In reference to the conserved name Leptocarpus, Rickett \& Stafleu listed the type of the rejected name Schoenodum as 'S. tenax Labillardière (vide Kunth, Enum. 3: 445. Jul 1841)', a reference that has persisted to the current edition of the ICBN.]

(4) Johnson and Evans (1966) observed that 'The female specimen was, in effect, selected as lectotype by R. Brown when he based L. tenax upon it'.

None of the publications mentioned effected lectotypification since they did not differentiate between the two taxa of Labillardière's female material or, in some cases, distinguish between Labillardière's female material and his illustration. Of these references, (1) and (2) did not use the term 'type', whereas (3) and (4) did not refer to a gathering of a single species. 
In the Webb Herbarium at FI there are male and female specimens relevant to S. tenax mounted separately on two sheets. Sheet FI 188030 bears flowering male culms, identifiable as Lyginia imberbis, and has a packet attached to the upper right corner labelled 'foem. flores', this contains an inner packet labelled 'semen cum fragmentiis capsulae'. The two pieces of material in the inner packet, however, appear to be staminal columns from male flowers of a Lyginia species. Four small handwritten sheets in Labillardière's hand are pinned to the sheet of this male material (FI 188030); the writing on two of these matches the text of the protologue of Schoenodum (p. 79) and S. tenax (p. 80); the other two are descriptive notes that appear to be a first draft of the description. Sheet FI 188031 bears groups of slender, unbranched culms, with three of the culms terminating in female inflorescences referrable to what is now called Apodasmia brownii. Also attached to FI 188031 are (1) a packet containing numerous female flowers of A. brownii, (2) a small packet labelled 'masculi flores' which contains male flowers of Lyginia and (3) a note 'facies chondropetali rotb.' in Labillardière's hand.

The relevant sheet in $\mathrm{P}$, of the taxon currently known as L. tenax, has a handwritten label (but not by Labillardière) 'Schoenodum tenax' and a printed label 'Van Diemén Labillardière Donné par M. Webb'. It bears a female plant with several culms and two inflorescences.

Sheet number 18267 in the Willdenow herbarium in B also bears a female specimen of the taxon currently known as L. tenax. It is labelled, in Labillardière's hand, 'Schoenodum tenax ${ }^{\hat{\sigma}}$ ' (sic.). The right-hand piece shows an inflorescence; the lefthand piece is only part of a culm, but its culm sheaths, and the ascending curve of a culm arising from a rhizomatous base, identify it as the same taxon.

It is now clear that Labillardière's female material is a mixture of two species, one represented by the material in FI and the other by the specimens in B and P. These are sufficiently similar to have been taken as conspecific (especially in the context of the male Lyginia material also being considered conspecific) when parts of the collections were chosen for close study and when duplicates were distributed. The description of vegetative structures may be based on all of the original material, of the three taxa, but with emphasis on the structures of the male, Lyginia, as in the description of the roots. However, it appears that material of only one of the female species was examined in detail and illustrated. The protologue of $S$. tenax describes the female inflorescence as 'panicula contracta, palmaris, spiculis elliptico-oblongis, sessilibus pedunculatisque, imbricatis squamis ovato-oblongis, acuminatis, unifloris.' The reference to ellipticoblong, single-flowered pedunculate spikelets is consistent with Labillardière's illustration (which shows a female inflorescence of distinct, elongated spikelets) and with the specimens in both $\mathrm{B}$ and $\mathrm{P}$. These features are characteristic of L. tenax, as that name is presently applied, and are not shown by the taxon known as A. brownii, which has much more condensed inflorescences, the spikelets not clearly distinguishable within the densely aggregated compound inflorescences, and the small flower-clusters each multiflowered.

Although the FI specimen is in the herbarium that houses Labillardière's main collection, it does not agree with the description and illustration of the female inflorescence in the protologue, which therefore cannot have been based upon it. Moreover, if the FI female specimen were chosen as lectotype, this would change the application of the names Leptocarpus tenax and Apodasmia brownii, causing confusion in the naming of two widespread and ecologically important species. 
The female specimens in $\mathrm{B}$ and $\mathrm{P}$ agree with the description and illustration of the protologue (in accord with Article 9.17 of the ICBN) and choice of either of them would preserve current usage of the names Leptocarpus and L. tenax. Only the specimen in B has been annotated by Labillardière, so this would appear the obvious choice among them. I therefore here designate as the lectotype of Schoenodum tenax Labill. the specimen on sheet 18267 of the Willdenow herbarium in B, which is female plant material of the taxon currently known as Leptocarpus tenax. A photograph of the lectotype is included in the microfiche set of the Willdenow herbarium (Inter Documentation Company microfiche set 7440). This lectotypification preserves the usage established by other authors who identified Schoenodum tenax with Labillardière's female gathering(s).

\section{The lectotype of Lyginia imberbis R.Br.}

Lyginia imberbis R. Br., the species to which Labillardière's male material is referred, is one of three species of the sole genus of Lyginiaceae (Briggs \& Johnson 2000), or a member of one of three genera of Anarthriaceae if a more inclusive family concept is adopted (Chase et al. 2000, Bremer 2002, APG II 2003), by which the Anarthriaceae encompasses the Anarthria clade of Briggs et al. (2000). Since the original material consists of Brown's collection and also Labillardière's illustration, lectotypification was necessary. Briggs \& Johnson (2000) overlooked the need for lectotypification and cited a sheet of Brown's collection, bearing both male and female plants, as the holotype. That incorrect use of a term to describe the type is an error to be corrected (ICBN Art. 9.8 ); it did not prevent the action of specifying a type among the original material effecting lectotypification. Thus the lectotype (designated [as 'holo'] by Briggs \& Johnson, Telopea 8: 496, 2000) is the specimen King George IIId $S^{\mathrm{d}}$ [Sound], R. Brown (Bennett No. 5837), 1802-5 (BM, ô, o mounted together on one sheet, annotated by Brown 'Restio', isolectotypes E, K, P).

\section{Acknowledgments}

Sincere thanks go to Gillian Perry for drawing my attention to relevant issues, many very helpful discussions of typification concerning these names and taxa, and numerous valuable comments on this manuscript. Dr David Mabberley kindly assisted with information concerning Robert Brown and Labillardière. Dr. P. Cuccuini provided photographs, a scan of Labillardière's specimens in FI and access to specimens in that herbarium. The assistance of G. Padovani, C. Nepi and A. Guiliano at FI, P. Morat and M. Pignal at P, J. Thurlow at MEL and M. Garcia at NSW is gratefully acknowledged. 


\section{References}

APG II (2003) An update of the Angiosperm Phylogeny Group classification for the orders and families of flowering plants: APG II. Bot. J. Linn. Soc. 141: 399-436.

Bremer K (2002) Gondwanan evolution of the grass alliance of families (Poales). Evolution 56: $1374-1387$.

Briggs BG (2001) (1489) Proposal to conserve the name Leptocarpus (Restionaceae) with a conserved type. Taxon: 50: 919-921.

Briggs BG \& Johnson LAS (1998) New genera and species of Australian Restionaceae (Poales). Telopea 7: 345-373.

Briggs BG \& Johnson LA (2000) Hopkinsiaceae and Lyginiaceae, two new families of Poales in Western Australia, with revisions of Hopkinsia and Lyginia. Telopea 8: 477-502.

Briggs BG, Marchant AD, Gilmore S \& Porter CL (2000) A molecular phylogeny of Restionaceae and allies. Pp. 661-671 in KL Wilson \& D Morrison (eds) Monocots-Systematics and Evolution.(CSIRO: Melbourne)

Brown R (1810) Prodromus Florae Novae Hollandiae et Insulae Van Diemen

Chase MW, Fay MF \& Savolainen V (2000) Higher-level classification in the angiosperms: new insights from the perspective of DNA sequence data. Taxon 49: 685-704.

Kunth CS (1841) Enumeratio Plantarum, vol. 3.

Labillardière JJH de (1806) Novae Hollandiae plantarum specimen, part 23.

Nelson EC (1974) The locations of collection and collectors of specimens described by Labillardière in 'Novae Hollandiae Plantarum Specimen' - additional notes. Pap. \& Proc. Roy. Soc. Tasmania 108: 159-170.

Rickett HW \& Stafleu FA (1959) Nomina generica conservanda et rejicienda spermatophytorum. Taxon 8: 213-243.

Manuscript received 18 October 2004, accepted 19 June 2005 